University of New Hampshire

University of New Hampshire Scholars' Repository

6-11-2014

\title{
Rural environmental concern: Effects of position, partisanship and place
}

Lawrence C. Hamilton

University of New Hampshire, Durham, lawrence.hamilton@unh.edu

Joel N. Hartter

University of New Hampshire, Durham, joel.hartter@unh.edu

Thomas G. Safford

University of New Hampshire, Durham, tom.safford@unh.edu

Forrest R. Stevens

University of Louisville

Follow this and additional works at: https://scholars.unh.edu/soc_facpub

Part of the Sociology Commons

\section{Comments}

This is the pre-peer reviewed version of the following article: Hamilton, L.C., J. Hartter, T.G. Safford \& F.R. Stevens.

2014. "Rural environmental concern: Effects of position, partisanship and place." Rural Sociology 79(2):257-281, which has been published in final form at https://dx.doi.org/10.1111/ruso.12023. This article may be used for noncommercial purposes in accordance with Wiley Terms and Conditions for Self-Archiving.

\section{Recommended Citation}

Hamilton, L.C., J. Hartter, T.G. Safford \& F.R. Stevens. 2014. "Rural environmental concern: Effects of position, partisanship and place." Rural Sociology 79(2):257-281. doi:10.1111/ruso.12023

This Article is brought to you for free and open access by the Sociology at University of New Hampshire Scholars' Repository. It has been accepted for inclusion in Sociology Scholarship by an authorized administrator of University of New Hampshire Scholars' Repository. For more information, please contact Scholarly.Communication@unh.edu. 
AUTHORS' DRAFT. Final version published in:

Rural Sociology (2014) 79(2):257-281. doi: 10.1111/ruso.12023

\section{RURAL ENVIRONMENTAL CONCERN EFFECTS OF POSITION, PARTISANSHIP AND PLACE}

Lawrence C. Hamilton

Department of Sociology

University of New Hampshire

Joel Hartter

Department of Geography

University of New Hampshire

Thomas G. Safford

Department of Sociology

University of New Hampshire

Forrest R. Stevens

Department of Geography

University of Florida

\section{ACKNOWLEDGMENTS}

The Communities and Forests in Oregon (CAFOR) project was supported by a grant from the Disaster Resilience for Rural Communities Program, which is part of the National Institute of Food and Agriculture program of the US Department of Agriculture (Award \#2010-67023-21705). Preliminary field data collection was funded by a graduate field research grant from the Mazamas Foundation; FRS was partially supported by the National Science Foundation under Grant No. 0801544 in the Quantitative Spatial Ecology, Evolution and Environment Program at the University of Florida. The Ketchikan and Southeast Alaska surveys received support from the USDA Rural Development program. Puget Sound surveys were funded by the U.S. Environmental Protection Agency, the National Oceanographic and Atmospheric Administration (National Marine Fisheries Service), and the College of Liberal Arts at University of New Hampshire. Other CERA surveys have been supported by grants from the Ford Foundation, Neil and Louise Tillotson Fund, the Office of Rural Development in the US Department of Agriculture, and the Carsey Institute at the University of New Hampshire. The UNH Survey Center conducted all telephone interviews for these surveys, while the Carsey Institute provided logistical and administrative support.

\section{KEY WORDS}

Environmental concern, conservation, rural, place effects, survey, working landscapes, Oregon, forestry, wildfire, climate change 


\begin{abstract}
The social bases of environmental concern in rural America resemble those for the nation as a whole, but also reflect the influence of place. Some general place characteristics, such as rates of population growth or resource-industry employment, predict responses across a number of environmental issues. Other relatively unique aspects of local society and environment matter as well. In this paper we extend earlier work on both kinds of place effects, first by analyzing survey data from Northeast Oregon. Results emphasize that "environmental concern" has several dimensions. Second, we contextualize the Oregon results using surveys from other regions. Analysis of an integrated dataset (up to 12,000 interviews in 38 U.S. counties) shows effects from respondent characteristics and political views, and from county rates of population growth and resource-based employment. There also are significant place-to-place variations that are not explained by variables in the models. To understand some of these we return to the local scale. In Northeast Oregon, residents describe how perceptions of fire danger from un-managed forest lands shape their response to the word "conservation." Their local interpretation contrasts with more general and urban connotations of this term, underlining the importance of place for understanding rural environmental concern.
\end{abstract}

\title{
INTRODUCTION
}

Rural communities often depend more directly on their environment and natural resources, compared with larger diversified cities. When environment or resources change, rural places face strong pressures and yet more constrained choices (Dunlap 2010; Molnar 2010). Some of their constraints are social, including historically-grounded perceptions about society-environment relations. Understanding how place-specific conditions influence environmental perceptions can be critical for changing communities that need to adapt as historical society-environment relations no longer hold (Devine-Wright 2013).

Ching and Creed (1997) emphasize the importance of place — both its metaphoric and geographic aspects - in shaping rural identity. Substantial work has been done on the social-psychological concepts of place attachment and place identification 2(Nielsen-Pincus et al. 2010; Devine-Wright 2013; Kyle et al. 2004; Nielsen-Pincus et al. 2010; Raymond 2010; Robbins et al. 2009; Rollero and De Piccoli 2010; Scannell Gifford 2010). These dimensions can influence people's perceptions or behavior toward their environment.

We also know that the sociological bases of public perceptions about environmental issues in rural areas broadly resemble those identified for the U.S. as a whole. On rural as well as national surveys, education and political orientation predict responses about environmental problems from local to global in scale (Hamilton and Keim 2009; Hamilton et al. 2010). Gender and age effects are widely reported; race effects tend to be issue-specific (Jones and Dunlap 1992; Dietz et al. 1998). Commonalities between urban, suburban and rural residents could increase with the blurring of value and belief differences (Lichter and Brown 2011), partly reflecting demographic change as ex-urbanites move to the country.

Changing demographics contribute to shifting views of the environment (Gosnell and Abrams 2011; Nielsen-Pincus et al. 2010; Robbins et al. 2009; Sharp and Clark 2008). Other place characteristics including local environment and resource-environment relations affect environmental views as well (Brehm et al. 2006; Hamilton and Keim 2009; Hamilton et al. 2010; Krannich et al. 2006; Stedman 2006; Stedman et al. 2006). Individual case studies can highlight aspects of environment-society relations that 
influence local concerns (Freudenburg and Gramling 1994). Expanding these into generalizations requires comparative data across many case studies. Certain general place characteristics, such as rates of population growth or employment in natural-resource industries, have shown impacts on environmental or resource issues (Gosnell and Abrams 2011; Hamilton et al. 2010; Henly 2012). Other relatively unique aspects of local environment, history, policy and regulations, land ownership, culture or economy also affect perceptions, behavior and resource management.

Previous research modeled both general and unique place effects, together with effects from individual characteristics, using data from a series of surveys conducted in 2007 for the Community and Environment in Rural America (CERA) initiative (Hamilton et al. 2010). Survey responses to environmental questions vary with respondent characteristics, much as expected, and also exhibit an education by political party interaction effect similar to that observed with climate-change questions (Hamilton 2008; Hamilton and Keim 2009). In addition, environmental views are influenced by county rates of unemployment, population change and natural resource-based employment. Adjusting for measured individual and place characteristics, analysis shows significant place-to-place variation caused by countless other ways in which places differ.

This work follows a long tradition of research on the social bases of environmental concern (Van Liere and Dunlap 1980), which now ranges from cross-national analyses (e.g., Marquart-Pyatt 2012; Pampel and Hunter 2012) down to the local level in rural America (e.g. Brehm et al. 2006; Stedman 2006; Stedman et al. 2006; Petrzelka et al. 2006). Social-bases research commonly starts from background or positional factors such as age, gender, ethnicity, education and income, together with worldview, ideology or values indicators that tend to be correlated with social position (e.g., Jones and Dunlap 1992;

Guagnano and Markee 1995; Klineberg et al. 1998; Dunlap et al. 2001; Dietz et al. 2005; 2007; Xiao and McCright 2007; Olofsson and Öhman 2008).

Inglehart (1995) linked values with social position by suggesting that environmentalist values flourish under "postmaterialialist" conditions of affluence. Inglehart and Baker (2000) developed this idea into a less linear path, more nuanced by place. Traditional values such as those in rural communities often persist in the face of demographic change, creating a distinct form of "modern" societies. Cross-national comparisons offer some support for a postmaterialist connection of comfort with environmentalism, but less so when subgroups within nations are considered - the wealthiest subgroups are not necessarily the most environmentalist (Brechin and Kempton 1994; Dunlap and York 2008; also see Dietz et al. 2005). For the U.S. in particular, ideological or political factors now show more consistent effects than social position, in predicting individual levels of environmental concern (McCright and Dunlap 2011b; Hamilton et al. 2010).

Education, knowledge and risk perceptions gain prominence where technical issues enter mainstream discussion (e.g., Vicusi and Zeckhauser 2005; Krosnick et al. 2006; Leiserowitz 2006; Slimak and Dietz 2006; Wood and Vedlitz 2007; Whitfield et al. 2009). Variations in risk perceptions account for some social-position results. For example, women often show higher concern regarding technology-driven risks. The disparity reflects women's higher assessments of personal and family dangers, and men's (especially, white males') higher confidence in their own knowledge (Davidson and Freudenburg 1996; Finucane et al. 2000; McCright and Dunlap 2011a; Xiao and McCright 2012). Age effects are also observed, with older respondents expressing lower levels of concern. Cohort differences provide one explanation (Van Liere and Dunlap 1980). Environmental topics gained 1970s counterculture significance, grew prominent through media attention and major federal legislation (Clean Air Act, Clean Water Act, Endangered Species Act), and became integrated with modern school curricula. The future 
impacts of environmental problems such as climate change could affect age differences in risk perceptions as well.

Some research has tested whether rural vs. urban residence predicts environmental concern. The heterogeneity of rural places (Freudenburg 2007) and the blurring of rural values or identity including newcomer/old-timer components (Abrams and Bliss 2013; Gosnell and Abrams 2011; Lichter and Brown 2011) contribute to mixed answers on this question. Case studies comparing several regions can address heterogeneity by describing what makes regions different, as illustrated by work on offshore oil development in coastal California, Louisiana and Florida (Freudenburg and Gramling 1994; Gramling and Freudenburg 1996, 2006; Hamilton et al. 2012a). When many places are compared, an alternative approach is to use measured characteristics of place as possible predictors. Ideally such place effects are evaluated while controlling for individual-level effects as well (e.g., Hamilton et al. 2010; Safford et al. 2012).

In this paper we take a layered methodological approach, looking first at one regional study and then 11 others for context, to replicate and extend earlier research on society-environment relationships in rural communities around the U.S. The analysis begins in Northeast Oregon, where our survey asked both general and locally-focused environmental questions. Some of the general questions have also been asked in other regions, providing a unique multi-regional perspective. Analyzing these data highlights both overarching patterns and place-to-place variations. To understand the place-to-place variations calls for a return to the local level, illustrated by the Northeast Oregon case.

\section{THE CAFOR PROJECT IN OREGON}

In 2010 an interdisciplinary research team began a study of Communities and Forests in Oregon (CAFOR). The study focuses on three counties (Baker, Union and Wallowa, combined population below $50,000)$ in the remote and mountainous northeast corner of the state (Figure 1). Almost half the land is managed by the federal government, including the Wallowa-Whitman, Umatilla and Malheur National Forests, Hells Canyon National Recreation Area, and the Eagle Cap Wilderness. Private industrial timber interests own a smaller but economically important fraction as well. Forest products from public and private lands, historically the economic mainstay of this region, have recently experienced hard times. Timber production fell drastically during the last two decades, led by a decline of more than $90 \%$ in federal land harvests. Overall harvest decline coupled with global competition, mill closures and rising costs for ranchers caused economic shocks that rippled throughout these three counties. National trends toward the divestment of large timber holdings, separating manufacturing and lands while consolidating mill infrastructure, have been felt here as well. More broadly, this region exemplifies a transitional mix of livelihoods tied to declining resource-based industries, alongside growing but not dominant amenitybased development. Similar transitions to varying degrees occur elsewhere throughout rural America today (Abrams and Bliss 2013; Gosnell and Abrams 2011; Krannich 2011; Nielsen-Pincus et al. 2010; Robbins et al. 2009; Wilson 2006; termed "amenity/decline" places in the typology of Hamilton et al. 2008).

Attracted by the area's natural amenities and available land, some retirees and people with remote careers or independent wealth made new homes in this region. At the same time, rising real estate prices and lack of family living-wage jobs have left many young residents unable to afford land, forcing some to move away or change livelihoods. Other long-term residents adapt by subdividing, selling or leasing their land to newcomers. Although there has been some rise in tourism, jobs in service and accommodation tend to 
be seasonal, not necessarily replacing the wages or benefits of forest-industry jobs. Partly reflecting socioeconomic shifts, conditions on forest lands are changing too, raising worries about wildfire. Among the changing economic and social conditions are some divisive environmental issues. Wind power presents one visible and controversial new development. Also controversial has been the reintroduction of wolves, which affects ranchers, game and livestock particularly in Wallowa County (Hamilton et al. 2012b).

CAFOR aims to characterize the interconnected socio-environmental changes taking place in this region, including how local residents perceive change and take action to adapt. One component involved a telephone survey of residents in the three-county region. Questions repeated core items from the CERA studies, supplemented by others developed for this region. Trained interviewers at the University of New Hampshire Survey Center conducted 1,585 interviews lasting about 10 to 15 minutes each during September and October 2011. Land-line phone numbers were selected at random within each of the three counties to obtain a cross-section of the public (overall response rate $48 \%$, calculated by the RR4 standard defined in AAPOR 2006). In addition, the survey oversampled forest landowners, who might hold views different from those of the general public. Probability weights (Lee and Forthofer 2006) compensate for this oversampling, and allow minor adjustments based on comparison with Census estimated age/sex/race tables for this region. Weighting also corrects for design bias related to household size and county population.

Table 1 lists environmental questions on the Oregon survey. Some of these (rules, conserve and climate) address general topics and have been used on other surveys. Conventionally environmentalist responses to these questions prove less popular in Northeast Oregon than nationally, but the same occurs in many resource-dependent rural areas. Other questions in Table 1 (wind, wolves and lands) have salience in Northeast Oregon, where wind power, the reintroduction of wolves, and management of public lands are subjects of hand-made billboards. The CAFOR survey also named seven potential problems, asking whether respondents thought each posed a serious threat to themselves or their community. Tabulations of responses from each county, including comparisons with forest landowners and national benchmarks, are given in Hamilton et al. (2012b).

\section{POSITION, PARTISANSHIP AND PLACE IN OREGON}

Results from regression of the first six environmental items (defined in Table 1) on individual characteristics and indicators for county appear in Table 2. ${ }^{i}$ Respondent's political party (coded -1 for self-identified Democrats, 0 for Independents and +1 for Republicans) dominates other predictors in these models. Republicans are less likely to perceive local benefits from environmental rules, to favor natural resource conservation for future generations, to believe that climate change is being caused by human activities, or to give wind and solar energy a higher priority than oil drilling. They are more likely to favor elimination of wolves from eastern Oregon, and to think that local needs should have priority over national interests in managing public lands. ${ }^{\text {ii }}$

Education (coded $-1=$ high school or less, $0=$ technical school or some college, $1=$ college graduate, and $2=$ postgraduate degree) is the second-most consistent predictor in Table 2 . The odds of conventionally environmentalist responses increase with education (at least, among Democrats and Independents) for most of these items. A negative education $\times$ party interaction effect occurs with respect to climate, as expected from earlier studies (Hamilton 2008, 2011, 2012; McCright and Dunlap 2011b). Among Democrats and Independents, education has a positive effect on belief that climate change is 
happening now, caused mainly by human activities. Education has a weak or negative effect on this belief among Republicans. Although the climate question asks about physical reality, many people form beliefs about this reality based on what they perceive to be its policy implication - that if anthropogenic climate change is real, then government intervention is needed. The land question invokes ideological position as well, and shows an interaction with opposite sign but similar meaning: education increases the odds of prioritizing local needs over national interests among Republicans, but not among Democrats.

Newcomer status (having lived in Northeast Oregon for less than 10 years) is the third-most consistent predictor in Table 2. Newcomers, commonly from more urban or suburban places, express greater support for conservation and anthropogenic climate change. They less often favor elimination of wolves, and tend to prioritize national interests ahead of local needs in land management. Similar newcomer/oldtimer divisions arise in other rural communities where natural amenities attract in-migration (Hamilton et al. 2010). In Northeast Oregon newcomers are no different from oldtimers in terms of education, but they are somewhat more likely to be Democrats, and much more likely to be young. The newcomer effect in Table 2 (and Table 3 ) represents the net effect of this status if we held education, politics and age constant.

Controlling for these individual predictors we also see place effects in the form of differences between counties. For example, wolf packs in this region live mainly in Wallowa County, where proportionately more residents favor their elimination. Wallowa County also has the greatest exposure to public forest lands -51 percent of land within the county is public and managed by the federal government. As discussed later, many people believe that misguided conservation plans exacerbate the hazard of wildfire.

Table 3 provides results from regressing responses about environment-related threats on the same set of predictors. Loss of forestry jobs, insects and wildfire are seen as serious threats by 75 to 85 percent of our respondents. Table 1 gives these percentages, and Table 3 shows that such concern is not partisan, nor is it related to most other demographics. These results emphasize that "environmental concern" has multiple dimensions. The social bases for Northeast Oregon residents' strong concern about forestry jobs, insects and wildfire do not resemble those for more conventionally environmentalist issues in Table 2 . Residents articulated this distinction in conversations with the researchers, emphasizing the importance of forest health while distancing their own views from those attributed to urban "environmentalist" others.

Concern about climate change (warming) shows a wide a partisan divide, confirming its wedge-issue status (McCright and Dunlap 2011b; Hamilton 2012). To a lesser degree, concerns about subdivision of forest properties (divide; this often involves higher intensity timber cutting, then reselling the land in smaller parcels for development, or for hobby farms and ranches) and overcutting (cutting; in this context, likely to be part of the same sales process when timber owners liquidate assets) have some partisan basis as well.

County differences show place effects after controlling for other factors. Wallowa County residents are more likely, and Baker County residents less likely, to see threats to their communities from loss of forestry jobs. These differences reflect their resource situations. Wallowa County has more commercial and productive forest land, but mill infrastructure has steeply declined. ${ }^{\text {iii }}$ Baker County on the other hand has less public forest land available or marketable for commercial harvest. People in both Wallowa and Baker Counties were unlikely (compared with Union County) to see a threat from overcutting, but their similar responses on that item arise for different reasons: for Wallowa residents the problem is not overcutting but too little cutting, associated with economic loss and fire danger. Overcutting is not problematic in Baker County either, but that is partly because forests account for a smaller fraction of the landscape and livelihoods. 
Thus, the individual background factors that predict responses on local and global environmental issues in Northeast Oregon broadly resemble those identified nationally and in other rural regions. More idiosyncratic place effects remain visible, however, in the contrasts between neighboring counties.

\section{REPLICATION ACROSS 12 REGIONS}

Two earlier papers (Hamilton and Keim 2009; Hamilton et al. 2010) analyzed place effects in data from more than 9,000 CERA interviews representing seven U.S. rural regions (19 counties), surveyed in 2007. From 2008 to early 2012, under continuations of CERA and related projects, more than 13,000 additional interviews were conducted in 12 mostly different regions (38 counties, parishes, boroughs or census areas - hereafter termed "counties" for brevity). ${ }^{\text {iv }}$ Table 4 summarizes the 2008-2012 surveys, including CAFOR in Northeast Oregon. The particular regions studied were not selected at random, but according to substantive interest and goals of individual projects. Overall, the regional selection aimed for socioeconomic and geographic diversity. Coastal regions were targeted in some surveys to complement the predominantly inland locations of earlier CERA work. ${ }^{v}$ Although the selection of regions is not random, random sampling and probability weighting were used to obtain representative samples within each region, and checked against regional census profiles.

Results from individual surveys have been presented in more than 30 reports (Carsey 2013) and articles (Hamilton et al. 2012a; Henly 2012; Safford and Hamilton 2011; Safford et al. 2012; Ulrich et al. 2013), which describe the individual study sites. Detailed tabulations of survey responses can be found in those sources. This section presents the first integrated analysis combining all of the 2008-2012 surveys, placing the Northeast Oregon results of Table 2 in broad context.

Table 5 shows the mixed-effects logit regression of rules, conserve and climate (as defined in Table 1) on individual and place characteristics. ${ }^{\text {i }}$ Gender, age, education and political party all show significant effects, in the positive or negative directions expected from previous research. Other things being equal, women are more likely to support conservation for the future instead of using resources now; and to believe that climate change is happening now, caused mainly by human activities. Older respondents are less likely to hold either view. Support for environmental rules, resource conservation, and belief in anthropogenic climate change all are more likely among better educated respondents, and less likely among Republicans. These education and partisan effects echo many previous studies, but here extend to locally-relevant environmental questions in rural areas, controlling for local conditions. Rules assesses perceptions of benefits from environmental rules in respondents' own communities. Conserve is a generational question as much as an environmental one. Climate invokes ideological beliefs about government, although these are not in the question itself or the scientific/physical reality. Typically, the climate question gets the most partisan response.

Basic logistic regression models, such as those in Tables 2 and 3, focus on the logit or log odds $(L)$ favoring one category of dependent variable $y$ :

$$
L_{i}=\ln \left[P\left(y_{i}=1\right) / P\left(y_{i}=0\right)\right]
$$

The log odds that $y$ equals 1 for the $i$ th observation are modeled as a linear function of the independent variables $\left(x_{1 i}, x_{2 i}\right.$ etc. $)$ :

$$
L_{i}=\beta_{0}+\beta_{1} x_{1 i}+\beta_{2} x_{2 i}+\ldots+\beta_{m} x_{m i}
$$

The intercept $\left(\beta_{0}\right)$ and slope coefficients $\left(\beta_{1} x_{1 i}, \beta_{2} x_{2 i}\right.$ etc.) in [2] are fixed, or constant across all observations in the data. In contrast, mixed-effects logit models such as those in Table 5 model the log 
odds that $y$ equals 1 for the $i$ th observation (individual) and the $j$ th cluster (county), as fixed effects from the independent variables $\left(x_{1 i j}, x_{2 i j}\right.$ etc.) plus a random intercept $\left(u_{0 j}\right)$ that could be different for each county:

$$
L_{i j}=\beta_{0}+\beta_{1} x_{1 i j}+\beta_{2} x_{2 j i}+\ldots+\beta_{m} x_{m i j}+u_{0 j}
$$

Coefficients in Table 5 are maximum-likelihood estimates of the $\beta$ parameters in [3]. ${ }^{\text {vii }}$ The random intercepts $\left(u_{0}\right)$ take on many different values (one for each county) in these models. Table 5 gives their estimated standard deviations, which all show significant variation. Random slope coefficients are possible in mixed-effects models as well, but in testing many alternative specifications we found no evidence supporting their inclusion. Random slopes complicate these models without significantly improving their fit.

i Weighted logit regression directly applies sampling weights to estimation of parameters, standard errors and tests. Results more realistically represent target populations within each region. For example, Wallowa County has a smaller population than Union or Baker, but was intentionally sampled at a higher rate. Weighted analysis adjusts percentages, regression coefficients and other calculations so that Wallowa responses have no more than proportionate impact.

ii Political party enters all regression models in this paper both through its main effect, and through its interaction with education. Main effects of party are interpreted as effects for a person with technical school or some college education (education $=0$ ). Similarly, main effects of education are interpreted as effects for a person self-identified as politically Independent (party $=0$ ).

iii Over the past twenty years, all four of the industrial-scale mills in Wallowa County closed down, compared with three of five in Union, and three of five in Baker (Hamilton et al. 2012b).

iv Most of these counties, etc. are classified as non-metropolitan, in keeping with CERA's rural focus. A few, such as Washington's King County or Louisiana's Terrebonne Parish, are metropolitan, but there too the natural environment and resources hold central importance for local economy and culture.

$v \quad$ A companion paper (Hamilton, Safford and Error! Main Document Only.WiesenMartin 2013) examines a set of specifically ocean-related environmental questions asked on the coastal-region surveys listed in Table 4.

vi Three measured county characteristics derive from U.S. Census data:

Population change from 2000 to 2010, as a percentage;

Unemployment rate, averaged for 2001-2010;

Resource employment, $\log _{10}$ of employment in agriculture, forestry, fishing, hunting or mining as a percentage of those employed in all industries. Values are for 2010 or, where those are unavailable, estimated by regression of nonmissing 2010 values on 2001-2007 values.

vii Both individual characteristics such as age, and county characteristics such as population growth, appear among the $x$ variables with fixed effects in Table 5. Although these models look different from the two-level formulation commonly used by multilevel modeling programs, the mixed-effects and multilevel-modeling approaches are mathematically similar. In practice, both are estimated through reduced-form equations along the lines of [3] (Rabe-Hesketh and Skrondal 2012). 
The negative education $\times$ party interactions in Table 5 mean that for all three dependent variables, environmental concern rises with education among Democrats, but does not rise and may even decline with education among Republicans. Education $\times$ party (or similar) interactions have been widely observed regarding climate-change dependent variables (Hamilton 2008, 2011, 2012; Hamilton and Keim 2009; Kahan et al. 2011, 2012; McCright 2011; McCright and Dunlap 2011b). They have less often been reported regarding non-climate environmental concerns (Hamilton et al. 2010). Biased assimilation (Lord et al 1979; Munro and Ditto 1997; Corner et al. 2011) and other differently-described but conceptually similar processes, through which people selectively acquire information that supports their pre-existing beliefs, may help to explain this phenomenon of information-elite polarization (Hamilton 2012). The ubiquity of political main and interaction effects in Table 5, as in Table 2, reflects national polarization across a range of environment or science-related questions (e.g., Dunlap et al. 2001; McCright and Dunlap 2011b; Gauchat 2012).

Table 5 also shows that in counties with more rapidly growing population (measured as the rate of change from 2000 to 2010), people are more likely to perceive benefits from environmental rules that restrict development. Conversely, where population is shrinking, people see less benefit from such rules. This intuitively reasonable place effect is visualized in Figure 2, which collapses more than 13,000 responses into 38 counties, graphing the weighted percentage of respondents who favor environmental rules against the rate of county population change. A robust regression line depicts the county-level trend, consistent with the positive logit coefficient in Table 5. ${ }^{\text {viii }}$ Figure 2 replicates Figure 6 (based on independent data) in Hamilton et al. (2010).

A negative coefficient in Table 5 indicates that approval of environmental rules tends to decline with the proportion employed in resource-based industries. Figure 3 visualizes this relationship in simplified form, again collapsing weighted survey responses by county. Figure 3 replicates Figure 4 in Hamilton et al. (2010).

The 38-county dataset is strongly clustered, motivating our mixed-effects modeling approach. Random intercepts in [3] allow for heterogeneity or differences in the mean response from each county. Even when values of all measured predictors are equal, odds of a particular response are higher in one county than another, due to the countless unmeasured differences between those places. Standard deviations of random intercepts in Table 5 show leftover but statistically significant county-to-county variation on all three environmental-concern measures. The next section revisits Northeast Oregon to understand what that means. 


\section{UNDERSTANDING RANDOM INTERCEPTS}

Figure 4 graphs estimates of the random intercepts on conserve, averaged for all respondents in each of 11 survey regions (conserve was not asked in a 12th region, Puget Sound). Most of the variation comes from two regions, Northeast Oregon and the Ketchikan Gateway Borough/Prince of Wales Census Area of Alaska. Negative random intercepts indicate that, even after adjustment for individual and place characteristics, support for resource conservation is notably lower in those two regions than elsewhere.

The CAFOR research team returned to Northeast Oregon in summer 2012 to present survey results for discussion at public and stakeholder meetings. One topic that often drew comments was the question conserve, which asks whether people think it is more important for their community to use natural resources now to create jobs, or to conserve resources for future generations. A number of residents remarked that they interpreted "conservation" to mean locking up land with access limitations and little or no tree harvesting, letting forests grow wild or unmanaged. This is a particularly contentious view involving the current state of forests, their management, and the heritage of working lands (Abrams and Bliss 2013). Although certain resources elsewhere, such as fish populations off Downeast Maine (largest positive intercept in Figure 4) would grow healthier without harvesting, Northeast Oregon forests are different. A dramatic reduction in cutting, particularly in areas where fire has been excluded, leads to changes in forest structure, fire regimes, species assemblages and riparian conditions. A century of fire suppression on the country's national forests (suppressing over $99 \%$ of unwanted wildland fires during initial attack; Dale 2006) has contributed to unnaturally dense stands with high fuel loads, supporting an increasing number of large, intense wildfires (Langston 1995; Agee 2003; Hessburg et al. 2004; Westerling et al. 2006; Raffa 2008). Vulnerability rises as a result of insect outbreaks, over-mature trees, or high stand density (Shindler and Toman 2003; Fairbrother and Turnley 2005). Decades of insect and disease mortality contribute to present-day fuel loads, and stand conditions that support large, severe fires (Hessburg et al. 2005).

Upward trends in wildfires in recent years have made them a concern in western communities historically dependent on forests and their ecosystems, or among the growing population that lives on a wildlandurban interface (Barbour et al. 2005; Dale et al. 2001; Huston 2005). Our Northeast Oregon discussants emphasized they do not support heedless over-harvesting, but believe that the term "conservation," which some associate with urban and left-leaning environmentalists unaware of local forest and community conditions, might imply curtailed or severely limited cutting. This contrasts with their own vision of stewardship and forest-community interconnection. According to this vision true "conservation" should reduce the threat of wildfire while also producing economic benefits. Feelings on this point were particularly strong in Wallowa County (see Table 2), which contains the highest proportion of federal forest land, and where there have been several recent large wildfires originating on federal land.

The largest negative random intercept for the rules model belongs to Ketchikan, Alaska (not shown). Environmental rules in that area are associated with government restrictions on access and harvesting in Tongass National Forest (Safford et al. 2011), and the 1997 closure of a pulp mill that had been dumping sludge and wastewater. The intercept for Northeast Oregon on the rules item also is negative, but less so than for Ketchikan.

Regarding climate, the third dependent variable in Table 5, a large positive intercept (not shown) occurs with our survey of North Country residents in northern Vermont, New Hampshire and Maine. In that snowy region a long-term trend toward warmer, shorter winters provides tangible evidence of climate change (Hamilton and Keim 2009). 


\section{CONCLUSIONS}

In rural places that sit at the uneasy crossroads between traditional resource-based production and new economies and cultures of aesthetic landscape consumption and diversified economies, ideas of landscape become increasingly important and contested (Lichter and Brown 2011; Walker and Fortmann 2003). Environmental value priorities shift along with changing livelihoods and the newcomer/oldtimer mix (Jones et al. 2003; Huddart-Kennedy et al. 2009). Case studies of particular rural regions can describe their character in some depth, qualitatively associating details of place with perceptions about environment and resources. Representative national surveys can step back to generalize about broader patterns, but they lack statistical power to resolve local details. Our hybrid approach, embedding regional case studies into multi-region analysis, aims to keep both special details and common patterns in view.

This analysis began with Northeast Oregon, where local issues involving wind power, wolves and public land management exhibit individual-level predictors similar to those for beliefs about global climate change. Other issues involving threats to local forests and forestry, however, evoke strong concern without education or partisan divisions. We also see differences between neighboring counties that reflect details of their environment and resources.

Placing the Oregon survey in a multi-region context yields a step-back perspective on place effects. Local rates of population change and resource employment predict individual perceptions of environmental rules in these data, much as they had in an earlier multi-region study. People in areas with growing population and low rates of resource-based employment are more likely to approve of environmental rules that restrict development, findings consistent with Inglehart and Baker's (2000) account of postmaterialism conditioned by place.

Integrated modeling highlights both patterns and notable exceptions. Returning to Northeast Oregon, we found an explanation for one notable exception in how people of that historically forest-dependent region interpret the word "conservation." They associate this term with no-harvest policies believed to heighten risks from insects and wildfires, while curtailing forestry-based livelihoods that have been the region's staple. More generally, they associate "conservation" with urban environmentalists who do not understand local conditions. The term urbanormativity (Thomas et al. 2011) is not common in local discourse, but could be applied to the hegemonic urban values perceived and contested by many rural residents.

Ching and Creed (1997) observe that social science focusing only on demographics tends to overlook the importance of place in shaping rural experience. Our analysis takes this to heart by doing both, starting with the better known demographic influences. Net of demographics, broad place characteristics also have demonstrable effects. Statistically removing demographic and broad place effects illuminates variation that needs interpretation through more specific details of each place - such as the dangers perceived from fire suppression and no-harvest policies in Northeast Oregon. Different details affect other regions, where understanding also requires awareness of local conditions. Examples from CERA include the contrasting imperatives of oil and tourism-based livelihoods in Gulf Coast Louisiana and Florida (Hamilton et al. 2012a), or of neighboring amenity/growth and declining-resource counties in Downeast Maine (Safford and Hamilton 2011). Historically rooted connections between environment and society shape outlooks in many rural communities, affecting the prospects for policies and new adaptation paths. 


\section{REFERENCES}

AAPOR. 2006. Standard Definitions: Final Disposition of Case Codes and Outcome Rates for Surveys, 4th edition. Lenexa, KS: American Association for Public Opinion Research.

Abrams, J. and J.C. Bliss. 2013. "Amenity Landownership, Land Use Change, and the Re-creation of 'Working Landscapes'." Society and Natural Resources 26(7):845-859.

Agee, J. K. 2003. "Monitoring Postfire Tree Mortality in Mixed Conifer Forests of Crater Lake, Oregon." Natural Areas Journal 23:114-120.

Barbour, R.J., M. Hemstrom, A. Ager, and J.L. Hayes. 2005. "Effects of Spatial Scale on the Perception and Assessment of Risk of Natural Disturbance in Forested Ecosystems: Examples from Northeastern Oregon." Forest Ecology and Management 211:210-225.

Brechin, S.R. and W. Kempton. 1994. "Global Environmentalism: A Challenge to the Post Material Thesis?” Social Science Quarterly 75:245-269.

Brehm, J.M., B.W. Eisenhauer, and R.S. Krannich, R.S. 2006. "Community Attachments as Predictors of Local Environmental Concern: The Case for Multiple Dimensions of Attachment." American Behavioral Scientist 50(2):142-165.

Carsey Institute. 2013. “Community and Environment in Rural America.” Durham, NH: Carsey Institute. Retrieved January 12, 2013 (http://carseyinstitute.unh.edu/cera).

Ching, B. and G.W. Creed, editors. 1997. Knowing Your Place: Rural Identity and Cultural Hierarchy. New York: Routledge.

Corner, A., L. Whitmarsh, and D. Xenias. 2011. "Uncertainty, Scepticism and Attitudes Towards Climate Change: Biased Assimilation and Attitude Polarisation." Climatic Change 114(3-4):463-478.

Dale, V.H., L.A. Joyce, S. McNulty, R.P. Neilson, M.P. Ayres, M.D. Flannigan, P.J. Hanson, L.C. Irland, A.E. Lugo, C.J. Peterson, D. Simberloff, F.J. Swanson, B.J. Stocks, and B.M. Wotton. 2001. "Climate Change and Forest Disturbances." BioScience 51:723-734.

Dale, L. 2006. "Wildfire Policy and Fire Use on Public Lands in the United States." Society and Natural Resources 19:275-284.

Davidson, D.J. and W.R. Freudenberg. 1996. "Gender and Environmental Risk Concerns: A Review and Analysis of Available Research.” Environment and Behavior 28:302-339.

Devine-Wright, P. 2013. "Think Global, Act Local? The Relevance of Place Attachments and Place Identities in a Climate Changed World.” Global Environmental Change 23(1):61-69.

Dietz, T., P.C. Stern, and G.A. Guagnano. 1998. "Social Structural and Social Psychological Bases of Environmental Concern." Environment and Behavior 30(4):450-471. 
Dietz, T., A. Fitzgerald, and R. Shwom. 2005. "Environmental Values." Annual Review of Environment and Resources 30:335-374.

Dietz, T., A. Dan, and R. Shwom. 2007. "Support for Climate Change Policy: Social Psychological and Social Structural Influences.” Rural Sociology 72:185-214.

Dunlap, R.E. 2010. "Climate Change and Rural Sociology: Broadening the Research Agenda." Rural Sociology 75(1):17-27.

Dunlap, R.E. and R. York. 2008. "The Globalization of Environmental Concern and the Limits of the Postmaterialist Values Explanation: Evidence from Four Multinational Surveys." The Sociological Quarterly 49:529-563.

Dunlap, R.E., C. Xiao, and A.M. McCright. 2001. "Politics and Environment in America: Partisan and Ideological Cleavages in Public Support for Environmentalism." Environmental Politics 10(4):23-48.

Fairbrother, A. and J.G. Turnley. 2005. "Predicting Risks of Uncharacteristic Wildfires: Application of the Risk Assessment Process.” Forest Ecology and Management 211:28-35.

Finucane, M.L., P. Slovic, C,K. Mertz, J. Flynn, and T.A. Satterfield. 2000. "Gender, Race, and Perceived Risk: The 'White Male' Effect.” Health, Risk and Society 2(2):159-172.

Freudenburg, W.R. 2007. "Rural-urban Differences in Environmental Concern: A Closer Look." Sociological Inquiry 61(2):167-198.

Freudenburg, W.R. and R. Gramling. 1994. Oil in Troubled Waters: Perceptions, Politics, and the Battle over Offshore Drilling. NY: State University of New York Press.

Fritsche, I., E. Jonas, D. Niesta Kayser, and N. Korany. 2010. "Existential Threat and Compliance with Pro-Environmental Norms.” Journal of Environmental Psychology 30:67-79.

Gauchat, G. 2012. "Politicization of Science in the Public Sphere: A Study of Public Trust in the United States, 1974 to 2010.” American Sociological Review 77(2):167-187.

Givens, J.E. and A.K. Jorgenson. 2011. "The Effects of Affluence, Economic Development, and Environmental Degradation on Environmental Concern: A Multilevel Analysis.” Organization and Environment 24(1):74-91.

Gosnell, A. and J. Abrams. 2011. "Amenity Migration: Diverse Conceptualizations of Drivers, Socioeconomic Dimensions, and Emerging Challenges.” Geojournal 76: 303-322.

Gramling, R. and W.R. Freudenburg. 1996. "Crude, Coppertone, and the Coast: Developmental Channelization and Constraint of Alternative Development Opportunities." Society and Natural Resources 9:483-506.

Gramling, R. and W.R. Freudenburg. 2006. "Attitudes Toward Offshore Oil Development: A Summary of Current Evidence." Ocean and Coastal Management 49:442-461. 
Guagnano, G.A. and N. Markee. 1995. "Regional Differences in the Sociodemographic Determinants of Environmental Concern" Population and Environment 17(2):135-149.

Hamilton, L.C. 2008. "Who Cares about Polar Regions? Results from a Survey of U.s. Public Opinion." Arctic, Antarctic, and Alpine Research 40(4):671-678.

Hamilton, L.C. and B.D. Keim. 2009. "Regional Variation in Perceptions about Climate Change." International Journal of Climatology 29(15):2348-2352.

Hamilton, L.C., C.R. Colocousis, and C.M. Duncan. 2010. "Place Effects on Environmental Views." Rural Sociology 75(2):326-347.

Hamilton, L.C. 2011. "Education, Politics and Opinions about Climate Change: Evidence for Interaction Effects." Climatic Change 104:231-242.

Hamilton, L.C. 2012. "Did the Arctic Ice Recover? Demographics of True and False Climate Facts." Weather, Climate, and Society 4(4):236-249.

Hamilton, L.C., T.G. Safford, and J.D. Ulrich. 2012a. "In the Wake of the Spill: Environmental Views along the Gulf Coast." Social Science Quarterly 93(4):1053-1064.

Hamilton, L.C., J. Hartter, F. Stevens, R.G. Congalton, M. Ducey, M. Campbell, D. Maynard, and M. Staunton. 2012b. "Forest Views: Northeast Oregon Survey Looks at Community and Environment." Issue Brief No. 47. Durham, NH: Carsey Institute, University of New Hampshire.

Hamilton, L.C., T.G. Safford, and D. Wiesen-Martin. 2013. "Environmental Views from the Coast: Public Concern about Local to Global Marine Issues." In review.

Henly, M. 2012. "Re-establishing Community Boundaries in Downeast Maine: Understanding the Roles of Ethnicity, Tenure of Residence, Economic and Environmental Conditions." The Journal of Rural and Community Development 7(2):18-36.

Hessburg, P.F., J.K. Agee, and J.F. Franklin. 2005. "Dry Forests and Wildland Fires of the Inland Northwest Usa: Contrasting the Landscape Ecology of the Pre-settlement and Modern Eras." Forest Ecology and Management 211:117-139.

Huddart-Kennedy, E., T.M. Beckley, B.L. McFarlane, and S. Nadeau. 2009. "Rural-urban Differences in Environmental Concern in Canada." Rural Sociology 74(3):309-329.

Huston, M.A. 2005. "The Three Phases of Land-use Change: Implications for Biodiversity." Ecological Applications 15(6):1864-1878.

Inglehart, R. 1995. "Public Support for Environmental Protection: Objective Problems and Subjective Values in 43 Societies." Political Science and Politics 15:57-71.

Inglehart, R. and W.E. Baker. 2000. "Modernization, Cultural Change, and the Persistence of Traditional Values.” American Sociological Review 65(1):19-51.

Jones, R.E., J.M. Fly, J. Talley, and H.K. Cordell. 2003. “Green Migration into Rural America: 
The New Frontier of Environmentalism?'” Society and Natural Resources 16:221-238.

Jones, R.E. and R.E. Dunlap. 1992. "The Social Bases of Environmental Concern: Have They Changed over Time?” Rural Sociology 57:28-47.

Kahan, D.M., H. Jenkins-Smith, and D. Braman. 2011. "Cultural Cognition of Scientific Consensus." Journal of Risk Research 14(2):147-174.

Kahan, D.M., E. Peters, M. Wittlin, P. Slovic, L.L. Ouellette, D. Braman, and G. Mandel. 2012. "The Polarizing Impact of Science Literacy and Numeracy on Perceived Climate Change Risks." Nature Climate Change 2:732-735.

Klineberg, S.L., M. McKeever, and B. Rothenbach. 1998. "Demographic Predictors of Environmental Concern: It Does Make a Difference How It's Measured." Social Science Quarterly 79:734-753.

Krannich, R., P. Petrzelka, and J. Brehm. 2006. "Social Change and Well-Being in Western AmenityGrowth Communities.” Pp. 277-292 in Population Change and Rural Society, edited by W.A. Kandel and D.L. Brown. Dordrecht: Springer.

Krannich, R.S., A.E. Luloff, and D.R. Field. 2011. People, Places and Landscapes: Social Change in High Amenity Rural Areas. New York: Springer.

Krosnick, J.A., A.L. Holbrook, L. Lowe, and P.S. Visser. 2006. "The Origins and Consequences of Democratic Citizens' Policy Agendas: A Study of Popular Concern about Global Warming." Climatic Change 77(1-2):7-43.

Kyle, G., A. Graefe, R. Manning, and J. Bacon. 2004. "Effects of Place Attachment on Users' Perceptions of Social and Environmental Conditions in a Natural Setting." Journal of Environmental Psychology 24(2):213-225.

Langston, N. 1995. Forest Dreams, Forest Nightmares. Seattle: University of Washington Press.

Lee, E.S., and R.N. Forthofer. 2006. Analyzing Complex Survey Data, 2nd edition. Thousand Oaks: Sage. Leiserowitz, A. 2006. "Climate Change Risk Perception and Policy Preferences: The Role of Affect, Imagery, and Values." Climatic Change 77(1-2):45-72.

Lichter, D. T., and D.L. Brown. 2011. "Rural America in an Urban Society: Changing Spatial and Social Boundaries.” Annual Review of Sociology 37:565-592.

Lord, C.G., L. Ross, and M.R. Lepper. 1979. "Biased Assimilation and Attitude Polarization: The Effects of Prior Theories on Subsequently Considered Evidence." Journal of Personality and Social Psychology 37(11), 2098-2109.

McCright, A.M., 2011. "Political Orientation Moderates Americans' Beliefs and Concern about Climate Change." Climatic Change 104(2):243-253.

McCright, A.M. and R.E. Dunlap. 2011a. "Cool Dudes: The Denial of Climate Change among Conservative White Males in the United States" Global Environmental Change 21:1163-1172. 
McCright, A.M. and R.E. Dunlap. 2011b. "The Politicization of Climate Change: Political Polarization in the American Public's Views of Global Warming.” Sociological Quarterly 52:155-194.

Marquart-Pyatt, S.T. 2012. "Contextual Influences on Environmental Concerns Cross-nationally: A Multilevel Investigation.” Social Science Research 41(5):1085-1099.

Molnar, J.J. 2010. "Climate Change and Societal Response: Livelihoods, Communities, and the Environment.” Rural Sociology 75(1):1-16.

Munro, G.D. and P.H. Ditto. 1997. "Biased Assimilation, Attitude Polarization, and Affect in Reactions to Stereotype-relevant Scientific Information.” Personality and Social Psychology Bulletin 23(6), 636653.

Nielsen-Pincus, M., T. Hall, J.E. Force, and J.D. Wulfhorst. 2010. "Sociodemographic Effects on Place Bonding." Journal of Environmental Psychology 30(4):443-454.

Olofsson, A. and S. Öhman. 2006. "General Beliefs and Environmental Concern: Transatlantic Comparisons." Environment and Behavior 38:768-790.

Pampel, F.C. and L.M. Hunter. 2012. "Cohort Change, Diffusion, and Support for Environmental Spending in the United States." American Journal of Sociology 118(2):420-448.

Petrzelka P., R.S. Krannich, and J. Brehm. 2006. "Identification with Resource-based Occupations and the Desire for Tourism." Society and Natural Resources 19:693-708.

Rabe-Hesketh, S., and A. Skrondal. 2012. Multilevel and Longitudinal Modeling Using Stata, 3rd edition. College Station, TX: Stata Press.

Raffa, K.F., B.H. Aukema, B.J. Bentz, A.L. Carroll, J.A. Hicke, M.G. Turner, and W.H. Romme. 2008. "Cross-scale Drivers of Natural Disturbances Prone to Anthropogenic Amplification: The Dynamics of Bark Beetle Eruptions.” BioScience 58(6):501-517.

Raymond, C.M., G. Brown, and D. Weber. 2010. "The Measurement of Place Attachment: Personal, Community, and Environmental Connections.” Journal of Environmental Psychology 30(4):422-434.

Robbins, P., K. Meehan, H. Gosnell, and S.J. Gilbertz. 2009. "Writing the New West: A Critical Review.” Rural Sociology 74(3):356-382.

Rollero, C. and N. De Piccoli. 2010. "Place Attachment, Identification and Environment Perception: An Empirical Study.” Journal of Environmental Psychology 30(2):198-205.

Safford, T.G. and L.C. Hamilton. 2011. "Demographic Change and Shifting Views about the Marine Coastal Environment in Downeast Maine.” Population and Environment 33:284-303.

Safford, T.G., J.D. Ulrich, and L.C. Hamilton. 2012. "Public Perception of the Response to the Deepwater Horizon Oil Spill: Personal Experiences, Information Sources, and Social Context." Journal of Environmental Management 113:31-39. 
Scannell, L. and R. Gifford. 2010. "Defining Place Attachment: A Tripartite Organizing Framework." Journal of Environmental Psychology 30(1):1-10.

Sharp, J.S. and J.K. Clark. 2008. "Between the Country and the Concrete: Rediscovering the Rural-urban Fringe." City and Community 7(1):61-79.

Shindler, B. and E. Toman. 2003. "Fuel Reduction Strategies in Forest Communities: A Longitudinal Analysis." Journal of Forestry 101(6):8-14.

Slimak, M.W. and T. Dietz. 2006. "Personal Values, Beliefs, and Ecological Risk Perception.” Risk Analysis 26(5):1689-1705.

Stedman, R. 2006. "Understanding Place Attachment among Second Homeowners.” American Behavioral Scientist 50(2):1-19.

Stedman, R.C. and R.B. Hammer. 2006. "Environmental Perception in a Rapidly Growing, Amenity-rich Region: The Effects of Lakeshore Development on Perceived Water Quality in Vilas County, Wisconsin." Society and Natural Resources 19:137-151.

Thomas, A.R., B. Lowe, G. Fulkerson, and P. Smith. 2011. Critical Rural Theory: Structure, Space, Culture. New York: Lexington Books.

Ulrich, J.D., M. Henly, and T.G. Safford. 2013. "The Push and Pull of Rural Places: The Role of Community Evaluations in Migration Intentions.” Rural Sociology (in press).

Van Liere, K.D. and R.E. Dunlap. 1980. "The Social Bases of Environmental Concern: A Review of Hypotheses, Explanations and Empirical Evidence.” Public Opinion Quarterly 44(2):181-197.

Viscusi, W.K. and R.J. Zeckhauser. 2005. "The Perception and Valuation of the Risks of Climate Change: A Rational and Behavioral Blend.” Social Science Research Network. Retrieved June 23, 2013 (http://ssrn.com/abstract=832645).

Westerling, A.L., H.G. Hidalgo, D.R. Cayan, and T.W. Swetnam. 2006. "Warming and Earlier Spring Increase Western US Forest Wildfire Activity.” Science 313: 940-943.

Whitfield, S.C., E.A. Rosa, A. Dan, and T. Dietz. 2009. "The Future of Nuclear Power: Value Orientations and Risk Perception.” Risk Analysis 29(3):425-437.

Wilson, R.K. 2006. "Collaboration in Context: Rural Change and Community Forestry in the Four Corners." Society and Natural Resources 19(1):53-70.

Wood, B.D. and A. Vedlitz. 2007. "Issue Definition, Information Processing, and the Politics of Global Warming." American Journal of Political Science 51(3):552-568.

Xiao, C. and A.M. McCright. 2007. "Environmental Concern and Sociodemographic Variables: A Study of Statistical Models." Journal of Environmental Education 38:3-13.

Xiao, C. and A.M. McCright. 2012. "Explaining Gender Differences in Concern about 
Environmental Problems in the United States." Society and Natural Resources 25:1067-1084. 
Table 1: CAFOR (NE Oregon) environmental beliefs and concerns, with weighted response percentages $(n=1,585)$. Simplified coding shown here corresponds to the models in Tables 2, 3 and 5; see Hamilton et al. (2012b) for response breakdowns by county and comparison with national results.

Rules: Have conservation or environmental rules that restrict development generally been a good thing for your community, a bad thing, or have they had no effect here? Coded 1 if good thing (23\%), 0 otherwise.

Conserve: For the future of your community, do you think it is more important to use natural resources to create jobs, or to conserve natural resources for the future? Coded 1 if conservation more important $(21 \%), 0$ otherwise.

Climate: Which of the following three statements do you personally believe? That climate change is happening now, caused mainly by human activities; it is happening now but caused mainly by natural forces; or climate change is not happening now. Coded 1 if happening now caused mainly by humans (37\%), 0 otherwise.

Wind: Which do you think should be a higher priority for the future of this country, increased exploration and drilling for oil, or increased use of renewable energy sources such as wind and solar? Coded 1 if renewable energy higher priority (56\%), 0 otherwise.

Wolves: Which of the following four statements about wolves in eastern Oregon comes closest to you personal beliefs? Wolves should be eliminated from eastern Oregon, limited hunting of wolves should be allowed, wolves should not be hunted but landowners compensated, or wolves should not be hunted and no landowner compensation is needed. Coded 1 if wolves should be eliminated (34\%), 0 otherwise.

Lands: When managing public lands, do you think we should give higher priority to meeting the needs of the local community, or broader needs and interests of America? Coded 1 if local needs higher priority (75\%), 0 otherwise.

For each of the following, do you think that these problems pose a serious threat to you or your community? Coded 1 if serious threat, 0 otherwise.

Forest: Loss of forestry jobs or income (85\%)

Insects: Insects (76\%)

Fire: Wildfire (75\%)

Move: Community changing as too many people move in or leave $(44 \%)$

Divide: Dividing and selling portions of large forest properties (43\%)

Warming: Global warming or climate change (39\%)

Cutting: Overharvesting or heavy cutting of timber (34\%) 
Table 2: Individual characteristics and county of residence as predictors of views on general and local environmental issues in NE Oregon. Coefficients and tests are from weighted logit regression models.

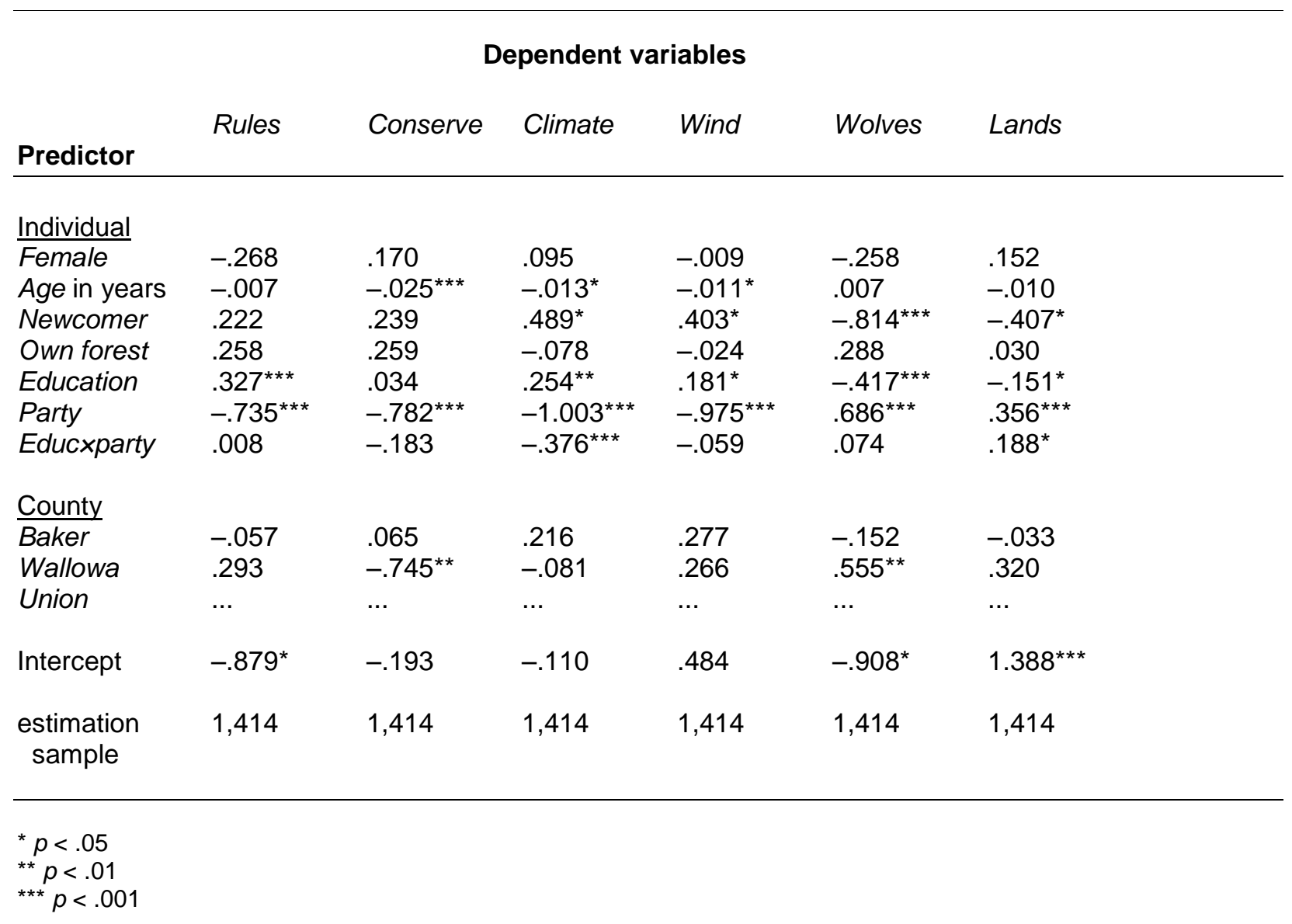


Table 3: Individual characteristics and county of residence as predictors of perceptions about environment-related threats in NE Oregon. Coefficients and tests are from weighted logit regression models.

\section{Dependent variables}

Forest Insects Fire Move Divide Warming Cutting

\begin{tabular}{|c|c|c|c|c|c|c|c|}
\hline \multicolumn{8}{|l|}{ Individual } \\
\hline $\begin{array}{l}\text { Female } \\
\text { Age in years } \\
\text { Newcomer } \\
\text { Own forest } \\
\text { Education } \\
\text { Party } \\
\text { Educxparty }\end{array}$ & $\begin{array}{l}.205 \\
.011 \\
-.242 \\
.483 \\
-.053 \\
.120 \\
.242^{\star}\end{array}$ & $\begin{array}{l}-.576^{\star *} \\
.007 \\
-.244 \\
.327 \\
.052 \\
.066 \\
.054\end{array}$ & $\begin{array}{l}.207 \\
-.005 \\
-.274 \\
.180 \\
-.042 \\
-.078 \\
.105\end{array}$ & $\begin{array}{l}.535^{\star * *} \\
-.019^{* * *} \\
-.158 \\
-.026 \\
-.110 \\
.021 \\
.051\end{array}$ & $\begin{array}{l}.105 \\
-.008 \\
.178 \\
-.239 \\
-.030 \\
-.309^{\star * *} \\
.107\end{array}$ & $\begin{array}{l}.356^{*} \\
-.012^{*} \\
.255 \\
-.014 \\
.026 \\
-1.133^{* * *} \\
-.069\end{array}$ & $\begin{array}{l}-.018 \\
-.003 \\
.180 \\
-.260 \\
-.210^{\star *} \\
-.497^{\star \star \star} \\
-.140\end{array}$ \\
\hline \multicolumn{8}{|l|}{ County } \\
\hline $\begin{array}{l}\text { Baker } \\
\text { Wallowa } \\
\text { Union }\end{array}$ & $\begin{array}{l}-.452^{*} \\
.483^{*} \\
\ldots\end{array}$ & $\begin{array}{l}-.274 \\
-.042 \\
\ldots\end{array}$ & $\begin{array}{l}-.112 \\
.256 \\
\ldots\end{array}$ & $\begin{array}{l}-.312 \\
.203 \\
\ldots\end{array}$ & $\begin{array}{l}-.393^{*} \\
.000 \\
\ldots\end{array}$ & $\begin{array}{l}-.122 \\
-.243 \\
\ldots\end{array}$ & $\begin{array}{l}-.653^{\star * \star} \\
-.403^{\star} \\
\ldots\end{array}$ \\
\hline Intercept & $1.101^{*}$ & $1.097^{* *}$ & $1.356^{\star * *}$ & .572 & -.031 & -.010 & -.184 \\
\hline $\begin{array}{l}\text { estimation } \\
\text { sample }\end{array}$ & 1,414 & 1,414 & 1,414 & 1,414 & 1,414 & 1,414 & 1,414 \\
\hline
\end{tabular}

${ }^{*} p<.05$

${ }^{* *} p<.01$

${ }^{* * *} p<.001$ 
Table 4: Community and Forest in Oregon (CAFOR), Puget Sound and Community and Environment in Rural America (CERA) surveys conducted by Carsey Institute researchers over 2008 to 2012.

Northeast Oregon (CAFOR)

September-October 2011: Baker, Union and Wallowa Counties in northeast Oregon $(n=1,585)$

Puget Sound

January-February 2012: King, Kitsap, Mason and Pierce Counties, in the Puget Sound area of

Washington $(n=1,302)$

Appalachia (CERA)

November 2010-January 2011: Harlan and Lechter Counties in coal country of Kentucky $(n=1,020)$

Columbia River (CERA)

January-February 2011: Clatsop County, Oregon and Pacific County, Washington $(n=1,023)$

Downeast Maine (CERA)

August-September 2009: Hancock and Washington Counties, on the northeast coast of Maine ( $n=$ $1,518)$

Gulf Coast Florida (CERA)

August-September 2010: Bay, Franklin and Gulf Counties along the eastern Gulf Coast of Florida ( $n=$ $1,005)$

Gulf Coast Louisiana (CERA)

Late July-September 2010): Plaquemines and Terrebonne Parishes in coastal Louisiana $(n=1,017)$

Ketchikan, Alaska (CERA)

June-August 2010: Ketchikan Gateway Borough and Prince of Wales Census Area in Southeast Alaska $(n=509)$

North Country (CERA)

June 2010: Coos County, New Hampshire; Essex County, Vermont; and Oxford County, Maine are adjacent in northern New England $(n=1,852)$

Olympic Peninsula (CERA)

October-November 2010: Clallam and Grays Harbor Counties, on Washington's Olympic Peninsula $(n=$ 1,013)

Southeast Alaska (CERA)

November-December 2010, with a small number of interviews in February 2011: Haines, Juneau, Sitka, Skagway, Wrangell and Yakutat Boroughs, along with the Hoonah-Angoon and Petersburg Census Areas, all in Southeast Alaska $(n=1,033)$

Upper Michigan (CERA)

August 2008): Alger, Chippewa, Luce, Mackinac and Schoolcraft Counties, on Michigan's Upper Peninsula $(n=1,008)$ 
Table 5: Individual and place-level predictors of views on environmental issues across 38 counties, etc. in 12 regional surveys. Coefficients and tests are from mixed-effects logit regression models with random intercepts for each county. Number of counties, surveys and estimation sample size vary depending on where a particular question was asked.

\section{Dependent variables}

\begin{tabular}{|c|c|c|c|}
\hline Predictor & Rules & Conserve & Climate \\
\hline \multicolumn{4}{|l|}{ Individual } \\
\hline Female & -.045 & $.246^{\star \star *}$ & $.136^{\star *}$ \\
\hline Age in years & .002 & $-.006^{\star * *}$ & $-.018^{* * *}$ \\
\hline Education & $.293^{\star \star *}$ & $.067^{\star \star}$ & $.182^{* \star *}$ \\
\hline Party & $-.389^{\star * *}$ & $-.387^{* * *}$ & $-.860^{\star * *}$ \\
\hline Educxparty & $-.142^{* \star *}$ & $-.123^{\star \star \star}$ & $-.275^{\star \star \star}$ \\
\hline \multicolumn{4}{|l|}{ County } \\
\hline$\overline{P o p ~ c h a n g e}$ & $.014^{\star}$ & .015 & -.001 \\
\hline Unemp rate & -.006 & -.002 & .007 \\
\hline Res employment & $-.301^{* *}$ & -.240 & -.203 \\
\hline Fixed int & $-.831^{* * *}$ & -.469 & $.683^{* *}$ \\
\hline \multicolumn{4}{|l|}{ Random int } \\
\hline $\begin{array}{c}\text { Counties/ } \\
\text { surveys }\end{array}$ & $38 / 12$ & $34 / 11$ & $31 / 10$ \\
\hline $\begin{array}{l}\text { estimation } \\
\text { sample }\end{array}$ & 12,332 & 11,232 & 10,031 \\
\hline
\end{tabular}

${ }^{*} p<.05$

${ }^{* \star} p<.01$

${ }^{* * *} p<.001$ 


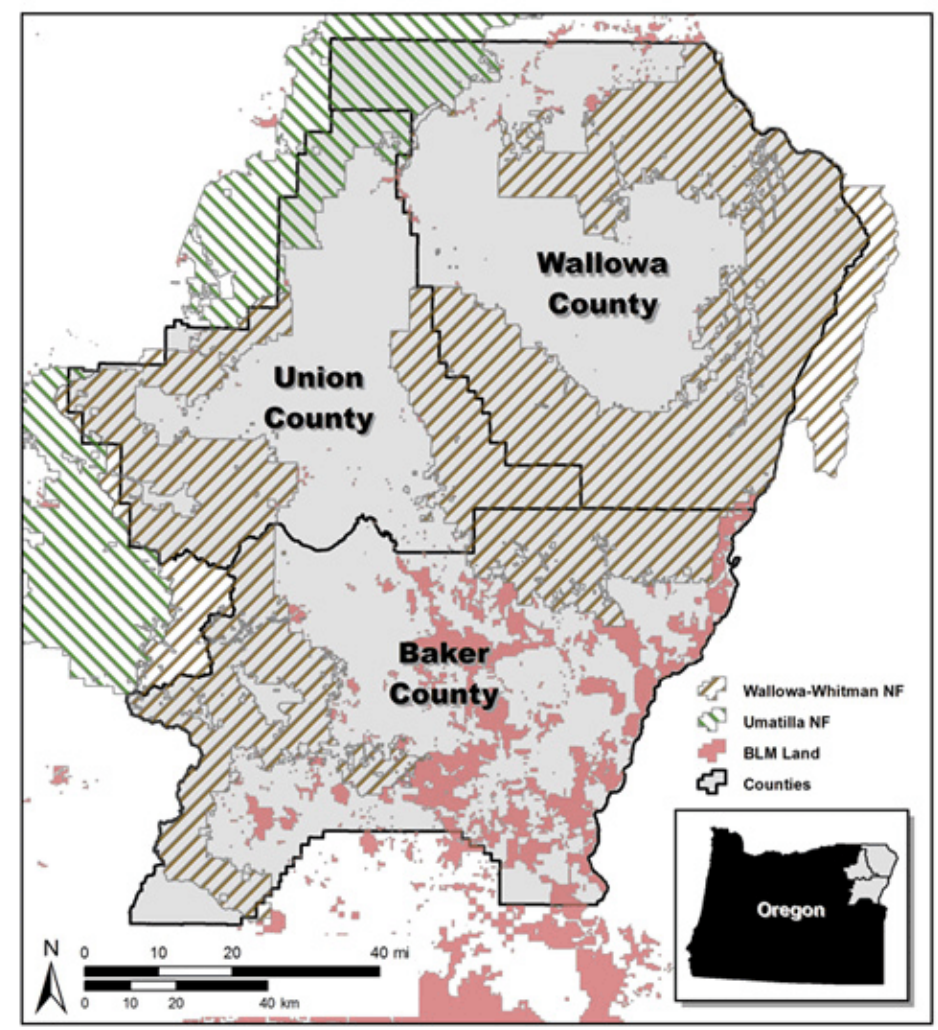

Figure 1: Map of the CAFOR study region in Northeast Oregon. 


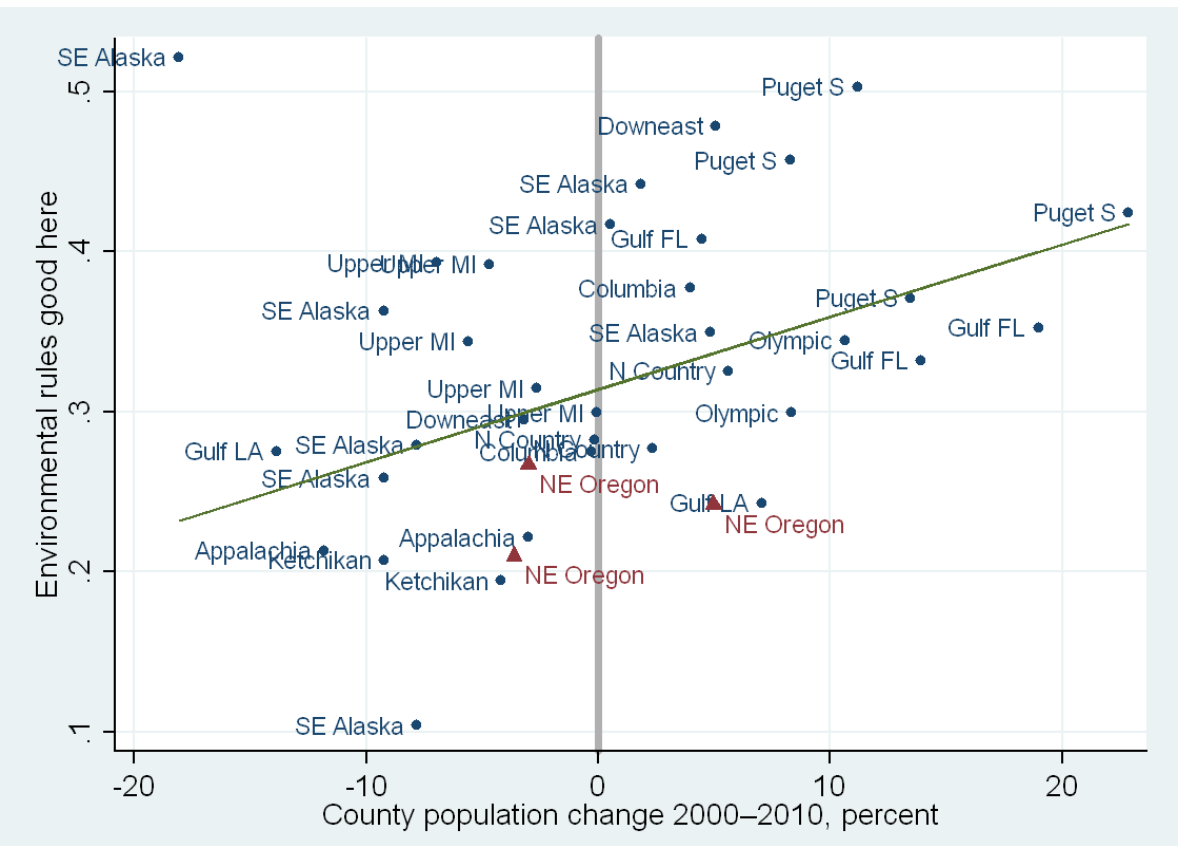

Figure 2: Weighted percent agreeing that environmental rules have been a good thing for their community, graphed against rate of population change in 38 counties of 12 regions. Shown with robust regression line.

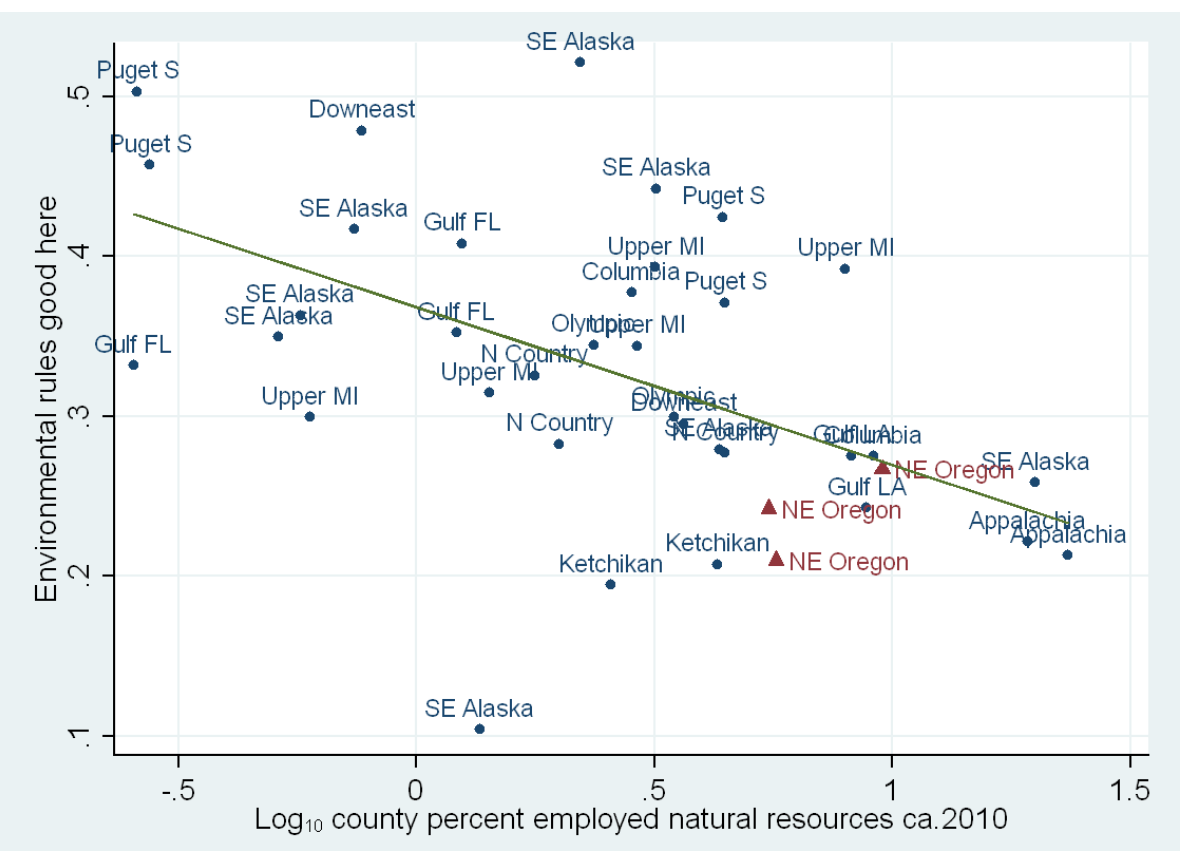

Figure 3: Weighted percent agreeing that environmental rules have been a good thing for their community, graphed against log percent employed in resource-based industries in 38 counties of 12 regions. Shown with robust regression line. 


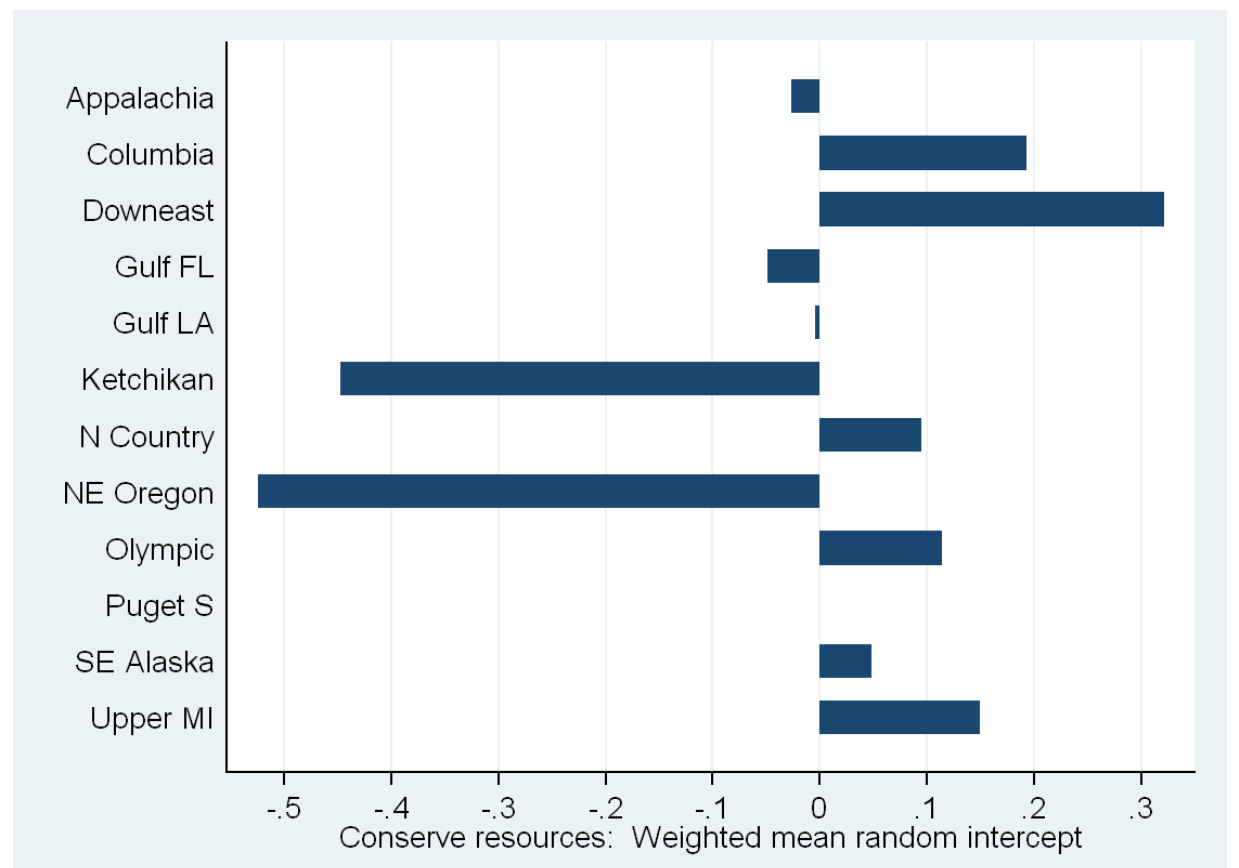

Figure 4: Mean of random intercepts by region, from the Conserve mixed-effects model in Table 5. (No data from Puget Sound on this item.)

\section{NOTES}

viii The obvious outliers in Figures 2 and 3 are two SE Alaska boroughs, Yakutat and Wrangell, where small survey sub-samples allow more erratic variation in survey percentages. Robust regression lines resist influence by outliers, and do not assume normality (Hamilton 2013). Conducting individual-level analyses with the full integrated dataset, it makes no practical difference if we set aside the smallest counties, so these are kept in for Table 5. 